[11] Khyzhna O., Lendel-Sarkevich A. (2018). Peace Education as Arts Education: In Search of New Strategies// Philosophy and Cosmology, Volume 21 The Academic Journal ISSN 2518-1866 (Online), ISSN 2307-3705 (Print), P. 74-84.

ДУДА И. Т., ЛЕНДЬЕЛ-СЯРКЕВИЧ А. А., СЕРБИН М. И. ТеатралИзацИЯ как ИНновацИонНаЯ технология исполнительской интерпретации в процессе профессиональной подготовки будущих учителей музыкального искусства.

В работе рассматриваются особенности внедрения технологии театрализации в прочесс профессиональной подготовки будущих учителей музыкального искусства в вузах, культурологический аспект которой теоретически переосмысливается в условиях изменения образовательной парадигмы.

Ключевые слова: культурологический подход, театрализация, исполнительская интерпретаџия, профессионально-педагогический потенциал, организационно-педагогическая система.

DUdA Y.T., LENDIEL-SIARKEVYCH A. A., SERbYNM. Y. Theatricalization as innovative technology of performance interpretation in the process of professional preparation of future teachers of musical art.

The author of the article considers issues of the category of movement in the field of choral art, dramatization of music as a result of interspecific synthesis of musical interpretation. The problem of methodological change of orientation in future music teachers training is investigated in the context of reformation of modern culturological education. It is important today that the main task of the pedagogical science is to make system of the pedagogical training of future teachers of a music.

Keywords: the culturological approach, the higher educational establishments, the choral music, the cultural environment, the professional and pedagogical potential, organization and pedagogical system.

DOI: https://doi.org/10.31392/NZ-npu-145.2019.06

УДК 378.23 .12

Думко Н. В.

\title{
ВРАХУВАННЯ ОСОБИСТІСНИХ ЗАПИТІВ КУРСАНТІВ ПОЛІЦІї НА ПОБУДОВИ ВЛАСНОЇ ТРАЄКТОРІЇ НАВЧАННЯ
}

У статі визначено особистісні запити курсантів поліиії на побудови власної траєкторії навчання. Задачі: визначити особливості побудови власної траєкторії навчання; з 'ясувати три основні лінії побудови власної траєкторії навчання курсантів поліиії. Працівник поліиії повинен професійно володіти усіма набутими компетентностями, дотримуватися принципів діяльності поліщії, оцінювати суспільні та економічні явища, виконувати покладені на поліцію завдання, приймати обтрунтовані рімення, поєднувати високий професійний рівень з моральністю $і$ культурою, бути здібним до ділового спілкування. Індивідуальна освітня траєкторія - це персональний шлях реалізаиії особистісного потенціалу кожного курсанта в освіті. Під особистісним потениіалом курсанта тут мається на увазі сукупність його здібностей - діяльнісних, пізнавальних, творчих, комунікативних та інших. Прочес виявлення, реалізачії та розвитку здібностей курсантів відбувається в ході освітнього руху курсанта за 
індивідуальними траєкторіями. Для максимальної реалізації власного навчального потенціалу студент повинен сформувати власну індивідуальну освітню траєкторію, яка передбачає вибір дисчиплін для вивчення й власне майбутню професію, що відповідатиме прагненням $i$ переконанням конкретного майбутнього фахівия.

Ключові слова: курсант полічіï, індивідуальна траєкторія навчання, фізична підготовка, тактична підготовка, комунікативні здібності.

Ключовим етапом євроінтеграції є реформування правоохоронної сфери. Система професійної підготовки працівників поліції потребує нагального перегляду та впровадження концептуально нових підходів і принципів їі функціонування. У відповідності до вимог закону України "про національну поліцію” до пріоритетних завдань підготовки курсантів поліції відносять надання поліцейських послуг, публічної безпеки і порядку, охорони прав і свобод людини, а також інтересів суспільства і держави та протидії злочинності У суспільстві $€$ потреба у фахівцях, які здатні професійно діяти, відповідно вирішувати завдання освіти у мінливих умовах соціальної реальності. 3 огляду на це актуальною стає проблема якісного перетворення системи підготовки курсантів поліції, яка має бути зорієнтована на формування і розвиток усіх складових професійної компетентності майбутніх поліцейських.

У теорії та практиці професійної освіти накопичено значний досвід, який може стати основою модернізації системи професійної підготовки курсантів поліції. Різні аспекти професійної підготовки майбутніх правоохоронців активно досліджували вчені різних галузей знань. Однак система професійної підготовки, а саме курсантів поліції ще не була предметом цілісного наукового дослідження в професійній педагогіці. Зокрема, не обґрунтовано й не розроблено моделі професійної підготовленості та готовності курсантів поліції до ефективного здійснення службової діяльності.

Для конкретизації особливостей і проблем фахової підготовки курсантів поліції розглянуто дослідження: М. Ануфрієва, О. Бандурки, О. Користіна, В. Синьова, В. Сокуренка, В. Пліска, Г. Яворської та ін. Об'єктом наукових інтересів з різних аспектів досліджуваної проблеми виступили: професійна підготовка фрахівців у вищій школі (А. Богуш, 3. Курлянд, І. Богданова, Е. Карпова, Н. Кічук, І. Княжева, А. Ліненко, І. Пальшкова, та ін.), професійна підготовка майбутніх працівників поліції, як соціальний і педагогічний процес (Г. Яворська, Г. Литвинова, О. Мисечко, В. Пліско, Р. Радзієвський та ін); підготовка майбутніх курсантів на підставі правової теорії діяльності поліції (Ю. В. Оболенського, С.В.Кузнєцова, Н. Л.Пономарьова); фрормування в поліцейських компетентностей 3 педагогіки (О. Топчій, С. Полудьонна, В. Михайліченко, П. Радомського). Зміст, певні аспекти формування соціальної зрілості були розкриті: Н. Новосьоловим, В. Юловим, Л. Машуковою, Ю. Дерябіним і В.Дерябіною; . Шумською й Ж. Завадською; Я. Галета. В. Радул охарактеризував та обґрунтував методику діагностики соціальної зрілості майбутнього педагога; Р. Хмелюк розкрила феномен "суспільної, професійної і соціальної зрілості” майбутнього викладача.

Мета статі - визначити особистісні запити курсантів поліції на побудови власної траєкторії навчання. Задачі: визначити особливості побудови власної 
траєкторії навчання; з'ясувати три основні лінії побудови власної траєкторії навчання курсантів поліції.

Методи дослідження: анкетування курсантів з метою їх ставлення до побудові власної траєкторії навчання; тестування 3 метою визначення комунікативних здібностей курсантів поліції; анкетування і бесіда щодо тактичної та фрізичної підготовки курсантів поліції.

Професійний розвиток майбутнього поліцейського $є$ складним довготривалим процесом, який передбачає не тільки поступовий перехід від одного етапу до іншого, а й виникнення професійних криз, які $є$ накопиченням як зовнішніх так і внутрішніх протирічь. У вітчизняній та зарубіжній психології можна умовно виділити три підходи щодо вивчення криз: 1) криза як результат зміни провідної діяльності і зміни соціальної ситуації, у співвідношенні 3 психічним розвитком (Л. Божович, Л. Виготський, В. Давидов, Д. Ельконін та ін.); 2) криза як внутрішнє (вроджене) прагнення особистості до розвитку, яке відбувається протягом усього життя (Б. Лівехуд, Е. Еріксон та ін.); 3) криза як зміна детермінанти розвитку у процесі життєвого шляху особистості (Дж. Ловінгер, Р. Хавігхерст та ін.).

Працівник поліції повинен професійно володіти усіма набутими компетентностями, дотримуватися принципів діяльності поліції, оцінювати суспільні та економічні явища, виконувати покладені на поліцію завдання, приймати обґрунтовані рішення, поєднувати високий професійний рівень з моральністю і культурою, бути здібним до ділового спілкування, а це, безумовно, буде сприяти підвищенню ефективності та результативності функціонування усієї системи МВC України. Розглядаючи профресійну діяльність працівників правоохоронних органів, зазначимо, що, відповідно до Закону України “Про Національну поліцію”, на поліцію в Україні покладені: адміністративна, профрілактична, оперативно-розшукова, кримінально процесуальна, виконавча та охоронна функції. Виконання службових завдань працівниками поліції в більшості випадків пов'язане з людським фактором, тобто з потребами, прагненнями, бажаннями, відчуттями, індивідуальними особливостями громадян - усім, що перебуває у сорері взаємовідносин “людина-людина".

Сучасний навчальний процес, орієнтований на якісну підготовку компетентного випускника, передбачає наявність освітньої програми, кожна частина якого поєднана з компетенціями й результатами навчання. 3 огляду на це, курсант поліції має можливість усвідомлено вибудовувати власну лінію освіти (унікальну послідовність вибраних модулів), орієнтовану на формування особистої професійної компетентності [5].

Створенню індивідуальної траєкторії навчання курсантів поліції, допомагає технологічні карти педагогічного тестування, що використовуються викладачем, відповідає вимог тестового контролю.

У технологічній карті відображають операції по здійсненню тестового контролю, виділяються основні напрямки корекції (за потреби, якщо вона доречна) процесу навчання.

Основним компонентом банку дидактичних засобів педагогічного 
тестування $є$ власне контрольно-вимірювальні матеріали - тести.

Проектування педагогічних тестів вимагає дотримання наступних правил: надійності та валідності; рівневої диференціації тестових завдань; поєднання доступності (посильності) і новизни (орієнтація на зону потенційного розвитку) в змісті тесту; варіативності тестових завдань.

Інформаційна карта студента також $€$ необхідним компонентом системи педагогічного контролю. Слід відзначити її особливу важливість як засобу забезпечення зворотного зв'язку, вона перетворює студента на активного учасника процедури контролю і оцінювання власної навчально-пізнавальної діяльності, дозволяє наочніше відстежувати прогрес в навчанні, а викладачеві - коректувати процес навчання з урахуванням потреб студентів.

Інформаційна карта студента має такі розділи (відповідно до логіки проведення тестового контролю): порядковий номер заняття; тема; прийом контролю (вид тестування); рівень виконання; оцінка/самооцінка; що мені було незрозуміло. Інформаційна карта заповнюється студентом, а потім вивчається й аналізується викладачем. Зокрема, під час рубіжного контролю (тематичного тестування) вона виступає як підстава для оцінювання діяльності студента 3 тієї або іншої теми.

За результатами дослідження основною освітньою траєкторією формування соціальної зрілості майбутніх поліцейськихє мовлення.

Побудови власної траєкторії навчання з мовлення, повинна сприяти наявністю інтересу та стійкої потреби у систематичному спілкуванні, емоційним задоволенням на всіх етапах комунікативної діяльності, здатністю осмислювати процес спілкування, сформованістю комунікативної культури та умінь й навичок взаємодопомоги, творчого спілкування з ровесниками, здатністю встановлювати та підтримувати необхідні контакти 3 іншими людьми.

Під час проведення першого етапу констатувального експерименту було виявлено рівень сформованості комунікативних здібностей курсантів поліції. Це дозволило з'ясувати, що більшість курсантів поліції має середній рівень вияву комунікативних здібностей та рівень нижче середнього. Отримані результати вимагали подальшої серйозної та планомірної роботи 3 формування комунікативних здібностей майбутніх поліцейських.

Результати позитивної зміни рівня сформованості комунікативних здібностей курсантів поліції наведено у табл. 1.

Табл. 1 свідчать про те, що по завершенню експериментальної роботи 3 застосуванням індивідуальної траєкторії навчання, курсантів поліції спостерігається динаміка розвитку комунікативних здібностей експериментальної групи у позитивну сторону: зросла кількість досліджуваних з дуже високим (на 6,1\% та 12,1\%) та високим (на 11,1\% та 35,5\%) рівнями комунікативних здібностей, відповідно зменшилась кількість досліджуваних 3 середнім рівнем (на 62,6\% та 41,5\%) та рівнем нижче середнього (на 20,3\% та 10,9\%). Позитивні зміни виявляються, насамперед, у прагненні курсантів поліції до комунікативної діяльності, у вмінні швидко орієнтуватися у складних ситуаціях, приймати самостійні рішення, відстоювати власну позицію, брати 
активну участь у суспільній діяльності, у свідомому прагненні вступати до контакту з оточуючими.

Табличя 1

Динаміка рівня сформованості комунікативних здібностей курсантів поліції (у\%)

\begin{tabular}{|l|l|l|l|}
\hline \multirow{2}{*}{ Рівні прояву } & \multirow{2}{*}{ Групи } & \multicolumn{2}{|l|}{ Комунікативні здібності } \\
\cline { 3 - 4 } & & До експ-ту & Після експ-ту \\
\hline \hline \multirow{2}{*}{ Дуже високий } & Контрольна & 6,1 & 7,2 \\
\cline { 2 - 4 } & Експер-на & 6,0 & 12,1 \\
\hline \multirow{2}{*}{ Високий } & Контрольна & 10,3 & 11,1 \\
\hline & Експер-на & 11,8 & 35,5 \\
\hline \multirow{2}{*}{ Середній } & Контрольна & 62,6 & 61,4 \\
\hline \multirow{2}{*}{ Нижче середнього } & Експер-на & 63,1 & 41,5 \\
\hline & Контрольна & 21,5 & 20,3 \\
\cline { 2 - 4 } & Експер-на & 19,1 & 10,9 \\
\hline
\end{tabular}

Наступна траєкторія навчання курсантів поліції це - фрізична культура.

Було провели анонімне анкетування з метою виявлення ставлення курсантів поліції до фрізичного виховання у позааудиторний час з метою покращення своєї індивідуальної траєкторії навчання з фрізичної культури.

В анкету було введено такі питання:

1. Чи вважаєте Ви за необхідне займатися в позааудиторний час фізичним вихованням?

2. Чи вважаєте Ви доцільним для власного життя займатися фрізичною культурою епізодично?

3. Чи залежить ваше здоров'я від самостійних занять фрізичними вправами вдома?

4. Чи вважаєте ви необхідним введення в практику з фізичного виховання нетрадиційних форм фізичної культури? молоді?

5. Яка головна причина, на Ваш погляд, низького рівня фрізичної культури

Результати подані в таблиці 2. Як ми бачимо (табл. 2.), студенти визнали за необхідне заняття з фрізичної культури (відповідно ОДУВС - 23,2\% / 24,6\%; ДДУВС - 21,9\%/22,5\%; ОЮА - 23,2\%/23,8\%) та бажане (ОДУВС $23,4 \% / 23,1 \%$; ДДУВС 22,3\%/20,4\%; ОЮА 22,6\%/21,9\%), вважають не обов'язковою (ОДУВС $53,4 \% / 52,3 \% ; \quad$ ЛЛУВС $55,8 \% / 57,1 \% ; \quad$ ОЮА $54,2 \% / 54,3 \%)$.

3 метою визначення певного розуміння щодо значущості фрізичної культури в житті майбутнього поліцейського й ставлення курсантів до фрізичної культури як частини загальної культури особистості було здійснено аналіз анонімного анкетування контрольних і експериментальних груп. Переважна кількість курсантівголовною причиною низької фрізичної культури молоді визначила: недостатню увагу викладачів до організації роботи з виховання 
фрізичної культури та відсутність нетрадиційних і нових методик і форм організації фрізичної культури. Респонденти у більшості випадків (90\%) мають власні бажання щодо втілення нетрадиційних методик у позааудиторну роботу, зокрема введення занять з йоги, корекційної гімнастики, аквааеробіки, фітнесу тощо. Переважна більшість респондентів на початку експерименту вважала, що не мають достатньо часу для рухових навантажень (51\%), а також достатньої інфрормації з галузі фрізичної культури (74\%).

Таблиця 2

\section{Ставлення студентів до занять з фізичної культури на початок експерименту} (в\% до кількості опитаних)

\begin{tabular}{|c|c|c|c|c|c|c|}
\hline \multirow[t]{2}{*}{$\begin{array}{lrr}\text { Ставлення } & \text { студентів до } \\
\text { занять } & 3 & \text { фізичної } \\
\text { культури } & & \end{array}$} & \multicolumn{2}{|c|}{$\begin{array}{l}\text { Одеський } \\
\text { державний } \\
\text { університет } \\
\text { внутрішніх } \quad \text { справ } \\
\text { (132 осіб) }\end{array}$} & \multicolumn{2}{|c|}{$\begin{array}{l}\text { Дніпровський } \\
\text { державний } \\
\text { університет } \\
\text { внутрішніх справ } \\
\text { ун-т (118 осіб) }\end{array}$} & \multicolumn{2}{|c|}{$\begin{array}{l}\text { Одеська } \\
\text { юридична } \\
\text { академія } \\
\text { ун-т (112 осіб) }\end{array}$} \\
\hline & $\begin{array}{l}\mathrm{K} \Gamma \\
\mathrm{y} \%\end{array}$ & $\begin{array}{l}\mathrm{E} \Gamma \\
\mathrm{y} \%\end{array}$ & $\begin{array}{l}\mathrm{K} \Gamma \\
\mathrm{y} \%\end{array}$ & $\begin{array}{l}\mathrm{E} \Gamma \\
\mathrm{y} \%\end{array}$ & $\begin{array}{l}\mathrm{K} \Gamma \\
\mathrm{y} \%\end{array}$ & $\begin{array}{l}\mathrm{E} \Gamma \\
\mathrm{y} \%\end{array}$ \\
\hline $\begin{array}{l}\text { 1. Ввважають } \\
\text { необхідне }\end{array}$ & 23,2 & 24,6 & 21,9 & 22,5 & 23,2 & 23,8 \\
\hline 2. Вважають за бажане & 23,4 & 23,1 & 22,3 & 20,4 & 22,6 & 21,9 \\
\hline $\begin{array}{l}\text { 3. Вважають } \\
\text { обов'язковою }\end{array}$ & 53,4 & 52,2 & 55,8 & 57,1 & 54,2 & 54,3 \\
\hline
\end{tabular}

Про усвідомлення необхідності фрізичної культури як якості для майбутніх фрахівців заявили $67 \%$ респондентів контрольної групи та $72 \%$ респондентів експериментальної групи. Про недостатній рівень психологічної і практичної готовності студентів до фрізкультурної діяльності свідчать ті фракти, що більша кількість студентів не може визначити поняття "фрізична культура" і тільки невеликий відсоток ототожнює це поняття з якістю особистості. За анонімним анкетуванням студентів I-III курсів велика кількість студентів вважає, що фрізкультурні заняття у позааудиторний час у вищих навчальних закладах не фрормують фрізичної культури майбутніх фрахівців (78\%). Причому $67 \%$ із кількості опитаних зводять роботу з фрізичної культури тільки до рухливих вправ. Так, тільки 22\% студентів 1 курсів вважають себе підготовленими до занять з фрізичної культури, відповідно II курсу - 28\%, III курсу - 30\%. Не повністю готовими до занять фрізичною культурою вважають себе $74 \%$ студентів I курсу, 68\% - II курсу, 65\% - третьокурсників. Всі ці фракти свідчать про невисокий рівень фрізичної культури курсантів поліції. Великий відсоток курсантів вважає, що фрізична культура особистості посідає другорядне місце поряд з іншими якостями сучасної людини. Так, із 78 студентів тільки 25 осіб фрізичній культурі відводять перше місце поряд з іншими якостями людини, 58 респондентів - вважають фізичну культуру бажану для сучасного молодого фрахівця, 41 студенти - не вбачають великої ролі фізичної культури в своєму житті. 
Третьою траєкторією навчання можна назвати - тактичну підготовку.

Тактична підготовка - це комплекс заходів, спрямований на набуття i вдосконалення поліцейським навичок практичного застосування теоретичних знань щодо правильного оцінювання конкретних подій 3 подальшим прийняттям правомірних рішень та психологічної готовності до дій у ситуаціях різних ступенів ризику[2].

Так, індивідуальні освітні траєкторії розробляються для кожної освітньої програми. Під індивідуальною освітньою програмою розуміється освітня програма студента, що фіксує індивідуальну освітню траєкторію, обрану студентом із запропонованих (нормативних) дисциплін, а також перелік дисциплін варіативної частини основної освітньої програми, що пропонуються студентові на власний вибір. Індивідуальна освітня траєкторія визначається на весь період навчання. Вибір траєкторії здійснюється після зарахування студента до вищого навчального закладу, але не пізніше ніж за місяць від початку занять.

Наприклад, запропонувати курсантам поліції заняття з тем: "Види зброї, які можуть застосовуватись". "Підготовка нарядів до несення служби патрульною поліцією”, “Основи тактики несення служби патрульною поліцією”, "Тактика поведінки працівників Національної поліції з метою уникнення небезпечних ситуацій”, "Основні повноваження Національної поліції”, “Порядок звернення до громадян",

Майбутній поліцейський приходить до розуміння необхідності вибору конкретних варіативних модулів при вивчені тактичної підготовки, виникає у кусанта поступово, у процесі їхнього дорослішання, освоєння ними базових модулів, занурення в професійно-орієнтоване освітнє середовище.

Висновок. Реалізація педагогічного тестування як засобу контролю за навчальним процесом забезпечує не лише діагностику і констатацію рівня навчальних досягнень, але й спрямована на підвищення якості освіти в цілому і відбудові індивідуальної траєкторії навчання курсантів поліції. Організація навчання за індивідуальною траєкторією вимагає особливої методики й технології. Індивідуальна освітня траєкторія - це персональний шлях реалізації особистісного потенціалу кожного курсанта в освіті. Під особистісним потенціалом курсанта тут мається на увазі сукупність його здібностей діяльнісних, пізнавальних, творчих, комунікативних та інших. Процес виявлення, реалізації та розвитку здібностей курсантів відбувається в ході освітнього руху курсанта за індивідуальними траєкторіями. Від сфрормованої індивідуальної освітньої траєкторії конкретного студента, від дисциплін, які він обрав для фрормування професійних компетентностей, залежить навантаження кафедри. Для максимальної реалізації власного навчального потенціалу студент повинен сформувати власну індивідуальну освітню траєкторію, яка передбачає вибір дисциплін для вивчення й власне майбутню профресію, що відповідатиме прагненням і переконанням конкретного майбутнього фахівця. 


\section{Використана література:}

1. Вакарчук I. Якість освіти i вільна траєкторія студента [Електронний ресурc]. URL: https://www.pravda.com.ua/articles/2009/04/28/3910314/

2. Тактико-спеціальна підготовка працівників Національної поліції : навч. посібник / О. І. Тьорло, Ю. Р. Йосипів, В. М. Синенький та ін. Львів : ЛьвДУВС, 2018. 480 с.

3. Матукова Г. І. Проблеми фізичного виховання студентської молоді. Педагогіка $i$ психологія формування творчої особистості. Проблеми пошуку: зб. наук. праць. Київ-Запоріжжя : Ін-туг педагогіки і психології проф. освіти АПН України ; Запорізький ОІ ППО, 2001. Вип. 18. С. 241244.

4. Федорук П. І. Технологія побудови індивідуальної адаптивної траєкторії навчання у системі дистанційної освіти і контролю знань / П. І. Федорук, М. В. Пікуляк. Математические машины и системы. 2010. Т. 1. № 1. С. 68-76.

5. Шаров С., Шарова Т. Формування індивідуальної освітньої траєкторії студента засобами інформаційної системи. Серія : Педагогіка. № 2 (19)'2017. http://eprints.mdpu.org.ua/id/eprint/2617/ 1/sharov_sharova_2017.pdf

\section{References:}

[1] Vakarchuk I. Yakist osvity i vilna traiektoriia studenta [Elektronnyi resurs]. URL: https://www.pravda.com.ua/articles/2009/04/28/3910314/

[2] Taktyko-spetsialna pidhotovka pratsivnykiv Natsionalnoi politsii : navch. posibnyk /O. I. Torlo, Yu. R. Yosypiv, V. M. Synenkyi ta in. Lviv : LvDUVS, 2018. 480 s.

[3] Matukova H. I. Problemy fizychnoho vykhovannia studentskoi molodi. Pedahohika i psykholohiia formuvannia tvorchoi osobystosti. Problemy poshuku: zb. nauk. prats. Kyiv-Zaporizhzhia: In-tut pedahohiky i psykholohii prof. osvity APN Ukrainy ; Zaporizkyi OI PPO, 2001. Vyp. 18. S. 241-244.

[4] FedorukP. I. Tekhnolohiia pobudovy indyvidualnoi adaptyvnoi traiektorii navchannia u systemi dystantsiinoi osvity i kontroliu znan / P. I. Fedoruk, M. V. Pikuliak. Matematycheskye mashynы у systemы. 2010. T. 1. № 1. С. 68-76.

[5] Sharov S., Sharova T. Formuvannia indyvidualnoi osvitnoi traiektorii studenta zasobamy informatsiinoi systemy. Seriia : Pedahohika. № 2 (19)2017. http://eprints.mdpu.org.ua/id/eprint/2617/1/sharov_sharova_ 2017.pdf

\section{Думко Н. Учет личностных запросов курсантов полиции для построения собственной траектории обучения.}

В статье определено личностные запросы курсантов полиции для построения собственной траектории обучения. Задачи: определить особенности построения собственной траектории обучения; выяснить три основные линии построения собственной траектории обучения курсантов полиции. Работник полиции должен профессионально владеть всеми приобретенными компетенциями, придерживаться принципов деятельности полиции, оценивать общественные и экономические явления, выполнять возложенные на полицию задачи, принимать обоснованные решения, сочетать высокий профессиональный уровень с нравственностью и культурой, быть способным к деловому общению. Индивидуальная образовательная траектория - это персональный путь реализащии личностного потенщиала каждого курсанта в образовании. Под личностным потенциалом курсанта здесь имеется в виду совокупность его способностей - деятельностных, познавательных, творческих, коммуникативных и других. Процесс выявления, реализаџии и развития способностей курсантов происходит в ходе образовательного движения курсанта по индивидуальным траекториям Для максимальной реализации собственного учебного потенциала студент долюен сформировать собственную индивидуальную образовательную траекторию, которая предусматривает выбор дисииплин для изучения и собственно будущей профессии, соответствующий стремлением и убеждением конкретного будущего специилиста .

Ключевые слова: курсант полииии, индивидуальная траектория обучения, физическая подготовка, тактическая подготовка, коммуникативные способности. 
DUмко N. Taking into account personal requests of police cadets to construct their own learning trajectory.

In the article by determine personal requests of police cadets to construct their own learning trajectory. Objectives: to determine the peculiarities of constructing your own learning trajectory; find out the three main lines of building your own cadre of police cadets training.

A police officer must have professionally acquired competences, observe police principles, evaluate social and economic phenomena, perform police tasks, make sound decisions, combine a high level of professionalism with morality and culture, be capable of business. An individual educational trajectory is a personal way of realizing the personal potential of each cadet in education. Under the personal potential of the cadet here means the totality of his abilities - activity, cognitive, creative, communicative and others. The process of identification, realization and development of the cadets' abilities takes place during the educational movement of the cadet on individual trajectories.

Individual educational trajectories are developed for each educational program. Individual educational program means a student's educational program that captures the individual educational trajectory chosen by the student from the proposed (normative) disciplines, as well as a list of disciplines of the variant part of the main educational program offered to the student of his choice. Individual educational trajectory is defined for the whole period of study. The choice of the trajectory is made after enrollment of the student in the higher education institution, but not later than one month after the beginning of classes.

Keywords: police cadet, individual trajectory of training, physical training, tactical training, communicative abilities.

DOI: https://doi.org/10.31392/NZ-npu-145.2019.07

УДК 37.371. 373.29

Іванова В. В.

\section{ОРГАНІЗАЦІЯ СУЧАСНОЇ ДОШКІЛЬНОЇ ОСВІТИ У СИСТЕМІ НЕПЕРЕРВНОÏ ОСВІТИ У КРАЇНАХ ЄВРОПЕЙСЬКОГО СОЮЗУ}

Велика увага приділяється в системах дошкільної освіти, підвищенню рівня та якості дошкільного навчання і підготовки дітей до школи як найважливішого чинника ӥх подальшого освітнього шляху аж до безперервної освіти “навчання впродовж усього життя".

У статті проаналізовано структуру сучасної дошкільної системи освіти у Великий Британії та у країнах Європейського союзу (Франції, Німеччині, Фінляндії, Польщі, Швейщаріі). Зазначено, щуо системи освіти иих країн мають свої особливості (у Великій Британії 93\% дошкільних закладів забезпечується державою; у Франції навчання дітей у материнській $i$ початковій школах здійснюється одним педагогом, щчо свідчить про ӥх тісний зв 'язок; у Данії значна частина вихователів - чоловіки, що має особливе значення для дітей з неповних сімей; $у$ Швейцарії існує дві конщепиії виховання дошкільнят, дві різні програми тощьо). У результаті дослідження встановлено, що спільним для дошкільних закладів європейських крайн є особлива увага до створення розвивального середовища та організащія різних видів діяльності, ще сприяє загальному розвитку дитини.

До структури дошкільної системи введена спеціальна ланка. - "передшкільний щабель” як сполучна ланка дошкільної та шкільної освіти, щзо орієнтує їх не лише на наступність, але й на інтеграцію (напр., старша група материнської школи у Франщї сполучена з першим класом початкової школи, у Швейцарї організовані комплекси: дитячий садок-икола тощо). 